\title{
The Impact of Service Quality AtTributes on Customers' TIPPING BEHAVIOR IN EgYPTIAN RESTAURANTS
}

\author{
Hossam Said Shehata \\ Lecturer, Hotels Studies Department \\ Faculty of Tourism and Hotels, Alexandria University
}

\begin{abstract}
The literature includes several studies that addressed the factors that motivate customers to leave tips, but most of these studies have been conducted in western countries and USA. On the other hand, there are little published researches that addressed such tipping motives in eastern countries. Therefore, this research investigates the impact of service quality on tipping behavior in Egypt. In order to answer the questions of this research, convenience sampling technique was employed and a total of 651 valid questionnaires were collected from Egyptian restaurant customers. Findings show that most Egyptians agreed that they tip in order to reward service quality. This research extends the body of knowledge on tipping as it is considered one of the first studies that addresses the tipping motives in an eastern country and whether it differs from western countries. Finally, restaurant managers should employ these findings to design training programs for service employees in order to raise their awareness of the most important reasons that stimulates customers' desire to tip.
\end{abstract}

Keywords: Tipping motives, service quality attributes, server friendliness, server attentiveness and Egypt

\section{Introduction}

The hospitality industry comprises a lot of organizations in private, public and voluntary ownership. In common with many other service industries, the competition for loyal customers is rife. These businesses provide an operating environment where competition is extremely intense and sustained. Such competitive conditions have led to many businesses trying to attract repeat customers in order to achieve long-term success (Douglas and Connor 2003). Therefore, hospitality companies have had to redefine themselves to reduce costs, enhance customer satisfaction, and gain a competitive advantage. The service-quality components have the greatest potential to create distinction (Kandampully et al., 2002). Since the 1970s, there has been a lot of attempts to study the concept of service quality. Although it has been argued that service quality is the great differentiator among service providers (Parasuraman et al., 1985), there has been no agreed definition of service quality. In the mid-1980s, Gronroos (1990) called for a definition of service quality that is capable of guiding management decisions; too often the term quality is used as if it was a variable itself and not a function of a range of resources and activities. He extended his definition of service quality to include two dimensions - technical and functional. An evaluation of 
'what' the customer receives in interactions with the service firm is technical quality, whereas 'how' the customer receives a service is called functional quality. Functional quality equates to the expressive performance of a service. Every customer comes with certain expectations about the quality of the products, the services, and the total experience of dealing with any business. When the product or service exceeds his expectations he perceives the quality as relatively high. When it fails to meet his expectation he perceives the quality as relatively low. In the back of customer's brain a scale that compares what he gets with what he expected (King and Woods 1996).

On the other hand, the importance of studying tipping was addressed from many perspectives. For example, Lynn and McCall (2000) confirmed the importance of studying tipping behavior as a great economic activity. They stated that tipping is a multimillion dollar economic phenomenon and being practiced world widely. In Canadian restaurants, for instance, people tip about 5 billion Canadian dollars each year (Azar, 2007). Moreover, the annual amount of tips given to employees working in the food industry in the United States of America is almost 42 billion dollars (Azar, 2009). Other researchers viewed the importance of tipping because it is a custom that directly affects hospitality workers and restaurant guests everyday (Whaley, 2011), and also affects the performance and profitability of service firms (Azar, 2011; Lynn and Withiam, 2008).Therefore, a better understanding of the determinants and dimensions of tipping would inform servers how to increase their incomes (Lynn, 2011). Despite the great presence of the tipping custom in every aspect of Egyptians' life, there is not any published scientific research that illustrated this phenomenon in the Egyptian market. Therefore, this research will realize the following objectives. Firstly, to identify the different service quality attributes that motivates customers to tip in Egyptian restaurants. Secondly, to arrange these attributes according to the degree of their impact on customers' willingness to leave tipping. Finally, to know the effect of the collective dimension of service quality on customers' tipping behavior.

\section{Literature Review}

The Concept of Service Quality. There were three approaches to define service quality from the customer point of view. In the first approach, service quality was defined according to customer needs and requirements. For example, Wyckoff (2001) defined service quality as the degree of excellence intended and the control of variability in achieving that excellence in meeting customer's requirements. In the second approach, it was defined according to the value achieved from a certain service. Garvin (1987) mentioned that a quality product is one that provides a high degree of performance at an acceptable price, as it supplies value. In the third approach, service quality was defined according to customers' expectations and perceptions. Hence, service quality is a measure of how well the service level delivered matches customer expectations (Lewis and Booms, 1983). Therefore, delivering quality service means conforming to customer expectations on a consistent basis.

The Importance of Service Quality in the Hospitality Industry. Service quality concerns all companies that recognize its effects on customer satisfaction and loyalty, especially in service sector, which is one of the major growth industries (Yesiltas et 
al., 2014). Furthermore, financial barriers of entry into the hospitality industry are minimal and as a consequence, there are always new providers adding to an already competitive situation. Moreover, the constant threat of substitute products or services has heightened the need to develop and maintain a quality approach to customer expectations and needs. It is difficult to maintain a repeat customer profile in such conditions where a plethora of organizations provide similar offerings, cost often being the deciding factor. However, if an organization emphasizes quality and good customer rapport, it may generate a loyal repeat customer base and eliminate the threat to the profitability and long-term survival of the organization (Douglas and Connor 2003).

Furthermore, customers are becoming increasingly critical of the quality of service they experience (Albrecht and Zemke, 1985). Customer demand and competition are forcing firms to cut loose from the traditional customer satisfaction paradigm, to adopt proactive strategies which will assist them to take the lead in the market-place. According to Berry et al. (1985), service quality has become a great differentiator and the most powerful competitive weapon which many leading service organizations possess. Service business success has been associated with the ability to deliver superior service (Gale, 1992). Delivering superior service by maintaining high quality is a prerequisite for success (Parasuraman et al.,1994). Leading service organizations strive to maintain a superior quality of service in an effort to gain customer loyalty (Zeithaml and Bitner, 2003); thus, a service organization's long-term success in a market is essentially determined by its ability to expand and maintain a large and loyal customer base. Generally, service quality promotes customer satisfaction, stimulates intention to return, and encourages recommendations. Customer satisfaction increases profitability, market share, and return on investment (Fornell, 1992).

Hospitality organizations with good service quality could improve their market share and profitability. In highly competitive hospitality organizations, managers must find ways to make their products and services stand out among the others. Moreover, the yardstick, by which an exceptional service organization may be measured, is its returning customer ratio - the loyal customer base. Evaluating the impact of service quality through customer retention will help measuring the financial impact of service quality (Zeithaml et al., 1996). Customer satisfaction leads to loyalty. While service organizations aim to gain customers' loyalty; customers, on the other hand, seek an organization's service quality as a proof of the organization's commitment to offering superior service, for both the present and the long-term.

Reviewing the literature reveals many studies that discussed the importance of service quality in the hospitality industry. For example, surveys conducted in the foodservice industry by the National Restaurant Association, have found that an insufficient amount of time, money, or effort is devoted to the development of skills necessary for managers and front-of-the-house employees in order to maintain adequate levels of service standards. It was mentioned that 25 percent of table service operators surveyed believed that service was the most important factor of the dining experience for their customers (National Restaurant Association, 1994). In 1996, when operators were asked which component was the most important to customers; both food and service had received equal ratings, whereas customer survey showed that service was the second most important component of a pleasant dining experience 
(National Restaurant Association, 1996). According to this significance placed on service by customers, foodservice managers need to be aware of the service standards necessary to meet the expectations of customers. Doubtless, customers define quality based on their expectations. Once the customers' expectations have been identified, service standards can be developed (Heskettet al., 1990). If foodservice managers understand the importance of service quality, they can stress the importance of maintaining quality service standards to employees. King (1995) mentioned that hospitality in the commercial context is a specific type of relationship between individuals - the hospitality service provider and customer. In this relationship, the host understands the needs and wants of the customer, which in return, will give pleasure to the customer and enhance her/his well-being and comfort. The host will deliver with generous and flawless face-to-face interactions. The objective is to enhance customer satisfaction and maintain repeat business.

Kandampully (1998) revealed that service quality is crucial to the success of any service organization. As the customers participate in the production and use of services, they interact closely with various aspects of the organization. This inside knowledge gives them the opportunity to assess critically the services provided, in particular the quality of service. Customers will assess service quality by comparing the service they get with the service they desire. Hence, service quality plays a critical role in adding value to the overall service experience. Since superior quality is one of the crucial factors within the control of the hospitality service provider, enhancing the quality of service at all levels of service delivery has therefore become mandatory for organization survival in the hospitality sector.

Zemke and Schaap (1989) mentioned four reasons why there is a shortfall in delivering quality service in hospitality organizations. First, companies fail to stay in touch with their customer needs. Second, society's perception of service-sector employees is poor. Third, management lacks responsibility for maintaining quality service. The fourth reason for poor service is that the employees responsible for customer contact are usually the lowest paid, least educated, and most poorly trained employees of the company. Accordingly, service managers must have a clear understanding of customers' expectations and perceptions; so that the service concept can be well defined, communicated and produced. Managers in the hospitality industry are faced with the dilemma of assuring that products and services are delivered by employees according to customer expectations. Training programs that utilize the most appropriate instructional design and tutorial techniques are needed to ensure that customers receive the service expected.

Linking Service Quality Attributes to Customers' Motivation to Leave Tipping. The growing literature on tipping behaviors suggests that service quality could impact the tipping behaviors, since the customers generally concern the level of good service before leaving tip (Yesiltas et al., 2014; Saunders and Lynn, 2010). For instance, Lynn (2009) found that the desire to reward good service quality is the most common motive for tipping reported by customers themselves. Previous studies have also found that restaurant customers tip more for better service, even when controlling for potential confounds and reverse causal effects (Lynn and McCall, 2000). Casey (2001) claimed that the main reason for tipping in New Zealand, is to appreciate the service. Additionally, Lynn and Graves (1996) indicated that tipping is related to customers' evaluations of service and the dining experience, but these relationships are weak. Furthermore, according to Azar (2004) the main justification for tipping is that it promotes better service, by giving the workers an incentive to do their best to satisfy 
the customer's needs. Maynard and Mupandawana (2009) have also reported that server's characteristics and perceived service quality have an impact on the tipping decision and tipping rates. Van Vaarenbergh and Holmqvist (2013) mentioned that customers who are served in their second language are less willing to tip due to the fact that they perceive a lower service quality.

Previous studies indicated that customers agreed that tipping exist because it is the most efficient way of monitoring and rewarding effort of service workers or as an incentive for good service delivered (Whaley et al., 2014; Lynn, 2009; Lynn and Withiam, 2008; Koku, 2005; Brauer, 1997). Economists have referred to this mechanism as a form of customer's monitoring of employee behaviors (Kwortniket al.,2009). The highly intangible nature of many services make it hard for service provider to control the quality services delivered by their employees, and tipping is the way of encouraging them to perform the high quality standard of service (Zeithamlet $a l ., 1988)$. The idea that people tip as a reward for good service is also consistent with equity theory (Adams, 1965; Walsteret al., 1973).

According to this theory, people are socialized to feel anxiety or distress when their relationships with others are unfair. A relationship is unfair when the participants' outcomes from the relationship are disproportionate to the irrespective inputs to the relationship. Since inequitable relationships are distressing, customers attempt to maintain equity in their relationships with servers by leaving larger tips when they receive better service (Lynn and McCall, 2000; Lynn and Graves, 1996; Lynn and Grassman, 1990; Snyder, 1976).

Tipping Behavior Around the World. Previous researches indicated that there are differences between countries in the tipping custom. This section illustrates tipping customs in different continents of the world will be. (1) North America: In some countries, like the United States, it is customary to tip many different service professions. Millions of restaurants, hotels, cruise ship, train employees, bus and taxis drivers depend heavily on tip income (Lynn, 2009;Lynn, 2000; Wessel, 1997). Speer (1997) conducted a nationwide telephone survey on tipping behavior in America, and used the results to summarize the views of "an average American". Average Americans maintain that the quality of service is the most important factor in leaving a tip. Helping those in the service industry to make a living is the second biggest reason Americans leave tips. A smaller group of Americans claim that they tip because they feel it is expected from them. Lastly, Americans tip because they feel that they will get better service the next time they dine at that particular establishment. In addition to those reasons, Conlinet al.(2003) asserted that people leave tips simply because it is the norm in the United States. Similar practices occur in Canada and Mexico (Zahari et al., 2011).(2) South America: In many South American countries customers add a service charge of about 10 percent, and a small tip on top of that is generally the norm. In Argentina and Brazil, the total customarily comes out to 13 to 15 percent. In Chile, Peru and Uruguay, 10 percent is average. Ecuador's norm is a little lower, about 7.5 percent (Loose, 2006).(3) Asia: Tipping norms differ between Asian countries. For example, in China, increasing number of service workers does not regard tipping as a voluntary behavior. Instead, they perceived tipping as a mandatory service charge and expect to get the full amount from each tipper (Dewald, 2003). Tipping in Hong Kong is the opposite of mainland China. Tips are socially acceptable, and often are an important part of etiquette. While tipping in local restaurants is not expected, tips in Western or upscale restaurants are happily accepted without offense (Rodgers, 2010). In Korea, tipping is not common in local restaurants; however, a small tip left in 
Western establishments is appreciated. In Thailand, locals generally do not tip each other; however, tourists are often expected to tip in luxury hotels and restaurants (Rodgers, 2010). In Japan, tipping is not a part of the culture. It is not expected and can cause confusion. Japanese people see tipping as insulting (Strand, 2014). In Singapore and Taiwan, tipping is not common. Bars and restaurants typically add a $10 \%$ service charge although it is not given to the wait staff, but rather considered by law as general revenue (Lin, 2013). In Saudi Arabia service charges arenot included in the bill; therefore tipping is expected in touristic areas. On the other hand, in Jordanian restaurants, although a service charge is included in the bill, tipping is still expected (Murphy, 2015).

(4) Europe: In countries, like Denmark, New Zealand, and Iceland; it is customary to tip only a few service professions (Zahari et al., 2011). In the United Kingdom, Ineson and Martin (1999) found that respondents who receive better service are more likely to leave a tip. Callan and Tyson (2000) conducted a study to compare tipping practices between English and Italian customers. They found that tipping as a means of showing status is significantly more important to the Italian than the English. Italian seems to be more generous in tipping waiters/waitresses than the English and this is because tipping in the UK now slowly being replaced by service charges and many believe that this trend will increase substantially. In central European countries, like Germany, Switzerland, Austria, and Holland; customers usually tip between 5-10\% of the bill although it is not always required to tip; while country like Spain, it is also not advocate of tipping (Zahari et al., 2011). (5) Australia: Tipping is not expected in Australian restaurants but waiters and waitresses do appreciate a 10 to 15 percent gratuity when offered. The reason why tipping is not required in Australia, is because every worker in Australia is legally entitled to a decent/livable wage (without any tipping), 4 weeks paid leave, paid sick leave and superannuation; otherwise, they received a very high hourly rate and thus tipping is absolutely not necessary to supplement a workers life style (Rotondo, 2014). (6) Africa: On the contrary to Australia, owing to lower salaries and wages among employees in the service sector including hotels and restaurants in African countries, tipping is one of the ways of supplementing their incomes (Zahari et al., 2011).In South Africa it is customary to tip good service. An acceptable amount is 10-15\%. Most service employees depend on tips to make up for the lower wages they receive (Murphy, 2015). In Morocco, tipping is an integral part of the deal for tourist services. The percentage of tipping is between $10-15 \%$ for taxis, $10 \%$ for hotels and between $5-10 \%$ for restaurants. In Ethiopia, tipping is common in hotels, restaurants and bars. One is also expected to tip parking lot attendants whether officially hired by institutions or self assigned (Hamilton, 2010). In other African countries, like Kenya, Nigeria, Ethiopia, Tanzania, Sudan, Uganda, Ghana, Mozambique, Angola, Madagascar, Cameron, Niger, Burkina Faso, Mali, Malawi, Zambia, Senegal, Chad, Zimbabwe, South Sudan, Rwanda, Guinea, Benin, Burundi, Togo, Liberia, Gabon and Namibia; employees are paid low wages and depend heavily on tips to supplement their incomes (Zahari et al., 2011).

\section{Hypotheses}

Based on the previous literature the following hypotheses are formulated:

H.: There is a significant positive relationship between service quality perceptions and customers' tendency to leave tipping. 
H.a: Server friendliness has a significant positive influence on customers' tendency to leave tipping.

H.b: Server attentiveness has a significant positive influence on customers' tendency to leave tipping.

H.c: The standing kind smile of service providers has a significant positive influence on customers' tendency to leave tipping.

H.d: Speed of service has a significant positive influence on customers' tendency to leave tipping.

H.e: Server knowledge of all information related to menu items has a significant positive influence on customers' tendency to leave tipping.

H.f: Server attractiveness has a significant positive influence on customers' tendency to leave tipping.

H.g: Good suggestions by waiters about menu items have a significant positive influence on customers' tendency to leave tipping.

\section{Methodology}

The development of the questionnaire began with a review of empirical and theoretical literature on service quality attributes that impact customers' tipping behavior. It was thus possible to extract valid, reliable questions and scales for each of the attributes under consideration. The questionnaire utilized in the current study comprised two sections. The first section of the questionnaire collected information on customer occupation-age, gender, scientific qualification, and social status. The second section of the questionnaire aimed to evaluate the impact of different service quality attributes - speed, attractiveness, knowledge of menu items, friendliness, kind smiling, attentiveness, and providing good suggestions by about menu items-on customers' tendency to leave tipping. This section utilized a Likert scale ranged from 1 strongly disagree to 5 strongly agree. Statements in this section were adapted from the existing literature (Lynn and Graves, 1996; Lynn, 2008; Lynn, 2009; and Becker et al., 2012.) The questionnaire also contained a section soliciting comments, thus offering participants the opportunity to express what is important to them regarding tipping. The comments obtained provided a suitable source of qualitative information which served to shed more light on the tipping behavior in Egyptian restaurants. The Cronbach's alpha coefficient for the questionnaire was measured at 0.92 . Therefore, the Cronbach's alpha coefficient is well above the 0.7 standard reliability suggested by Nunnally (1978) and Schmitt (1996).

According to the aim and hypotheses of this study; customers were invited to participate in the study and a total of 663 customers responded to the questionnaire. From this number only 12 questionnaires were invalid. Thus, 651 restaurant customers who had been reached, by using non convenience sampling method, were asked to contribute the survey. The survey was conducted in March and April 2015.It took between 10 and 15 minutes to complete. Participation was voluntary and anonymity was ensured.

\section{Results}

Profile of respondents. Using descriptive statistics, i.e. frequency and percent, the demographic characteristics of the respondents are analyzed and reported. Tabulated features of customers' profile included gender, social status, age, scientific qualification and occupation are shown in Table (1). 
Regarding the demographics of customers; data indicated that male customers represented $63.9 \%$, while $36.1 \%$ of respondents were female. As for the social status of the respondents; the highest percentage was for married customers $(67.1 \%)$, followed by singles $(28.6 \%)$, and others $(4.3 \%)$. By studying the age of respondents; it was apparent that most customers $(42.4 \%)$ were in the age category of "from 30 to less than 40 ". The least proportion reported $(1.2 \%)$ was for the category of "equal to or more than 60". In view of their scientific qualifications; the largest proportion of customers $(47.6 \%)$ had a university degree, and $33.7 \%$ had a doctorate or master degrees, while a limited proportion of them are either students $(4.4 \%)$, or had other degrees $(14.3 \%)$.In terms of occupation; there was a high proportion of respondents working in tourism-related jobs (20.3\%), while $19 \%$ of total respondents hold a managerial positions in their properties (e.g., top level managers, middle level managers and first level managers). Governmental employees, university staff members and students represented $24.4 \%$ of the sample. Due to the large number of other positions that responded to the questionnaire (e.g., Teachers, Engineers, Geologists, physicians, Workers, Journalists, IT specialists, Public relations professionals, Artists, etc...) and the few numbers within each position they have been assembled in one group named other positions and made up $36.3 \%$ of customers.

Table1: Profile of Respondents

\begin{tabular}{|c|c|c|}
\hline Demographic Characteristics & Frequency & $\%$ \\
\hline \multicolumn{3}{|l|}{ Gender } \\
\hline Male & 416 & 63.9 \\
\hline Female & 235 & 36.1 \\
\hline \multicolumn{3}{|l|}{ Social Status } \\
\hline Single & 186 & 28.6 \\
\hline Married & 437 & 67.1 \\
\hline Others & 28 & 4.3 \\
\hline \multicolumn{3}{|l|}{ Age } \\
\hline Less than 20 Years & 24 & 3.7 \\
\hline From 20 to Less than 30 & 207 & 31.8 \\
\hline From 30 to Less than 40 & 276 & 42.4 \\
\hline From 40 to Less than 50 & 120 & 18.4 \\
\hline From 50 to Less than 60 & 16 & 2.5 \\
\hline Equal to or More than 60 & 8 & 1.2 \\
\hline \multicolumn{3}{|l|}{ Scientific Qualification } \\
\hline University Degree & 310 & 47.6 \\
\hline Doctorate Degree & 128 & 19.7 \\
\hline Student & 29 & 4.4 \\
\hline Higher Technical Institute & 35 & 5.4 \\
\hline Master Degree & 91 & 14.0 \\
\hline Postgraduate Diploma & 45 & 6.9 \\
\hline
\end{tabular}


Technical Secondary School

\section{Occupation}

Tourism-related Jobs

Managers

Gov. Employees

University Staff

Students

Other Positions
13

132
124
24
80
55
236

2.0

Descriptive Statistics. This section reports the descriptive analysis performed utilizing means, percent, and frequencies. Presentation of the descriptive analysis is shown in Table (2). This part aims at illustrating a general view of the findings; and evaluating to what extent customers are motivated to leave tips for certain service quality attributes; as well as determining the most and least important attributes from customers' point of view.

As tabulated in table (2), a high proportion of respondents agreed that rewarding service quality is a very important motive for tipping (Overall Mean= 3.93). In this regard; 'Server friendliness' $(M=4.38)$ was the most influential reason for tipping from customers' perspectives, followed by 'server attentiveness' $(M=4.24)$, and 'the standing kind smile of service providers' $(M=3.99)$. On the other hand, least influential reasons for tipping in this dimension were 'server attractiveness' $(M=3.70)$ and 'good suggestions by waiters about menu items' $(M=3.50)$. The second variable 'tipping behavior' was represented by three statements with an Overall Mean of 3.92. Among the three statements; 'Tipping is a good way to motivate servers to take care of customers' recorded a highest score $(M=4.2)$, while the statement 'I support the custom of tipping' recorded the lowest agreement $(M=3.6)$. This result reveals that customers leave tips in order to guarantee a good service more than the fact that it is a personal passion.

Table 2: Frequencies and Means for the Research Variables

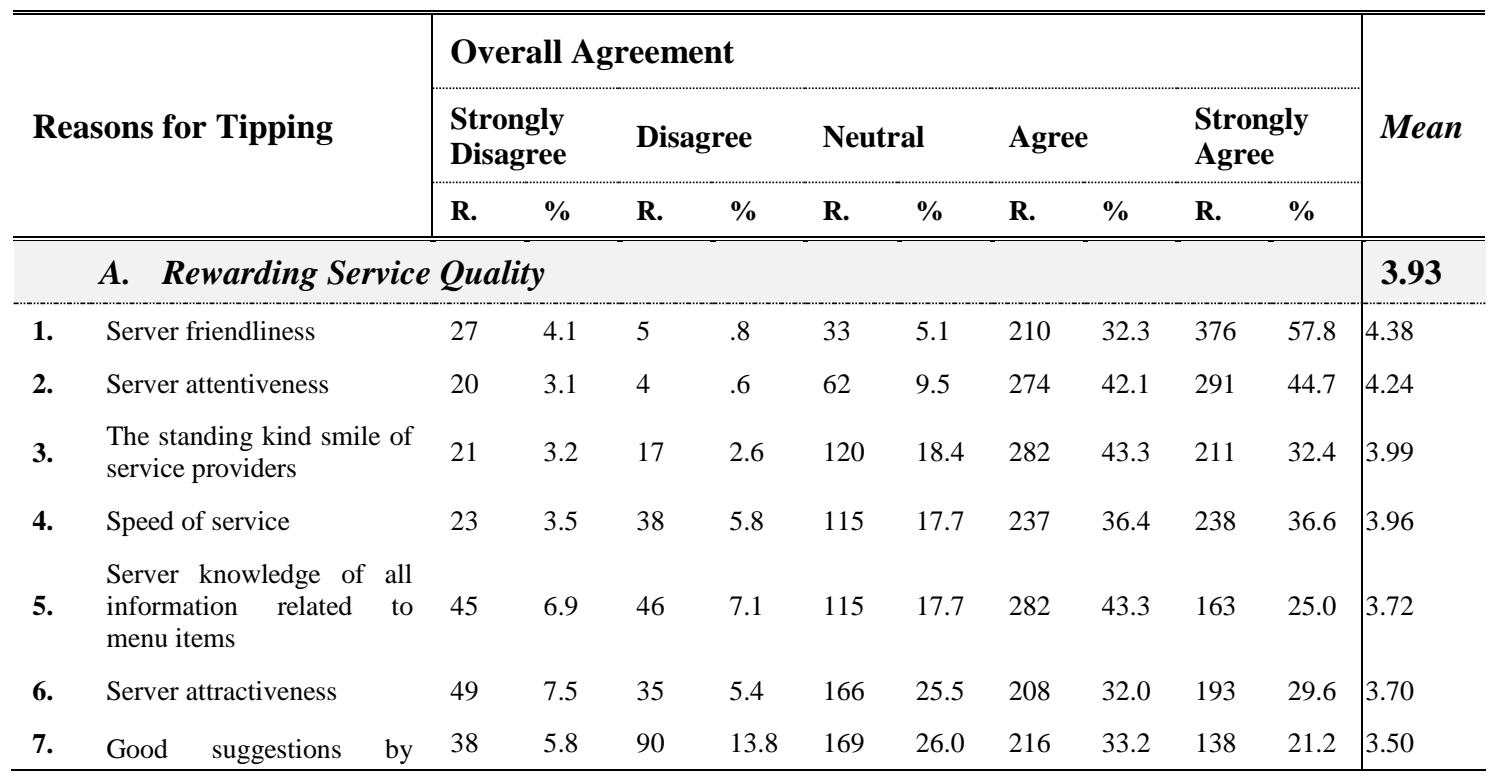




\begin{tabular}{|c|c|c|c|c|c|c|c|c|c|c|c|c|}
\hline & B. Tipping Attitude an & $d B$ & avior & & & & & & & & & \multirow{2}{*}{\begin{tabular}{|l}
$\mathbf{3 . 9 2}$ \\
4.00
\end{tabular}} \\
\hline 1. & $\begin{array}{l}\text { I like having to tip waiters } \\
\text { and waitresses }\end{array}$ & 49 & 7.5 & 15 & 2.3 & 68 & 10.4 & 252 & 38.7 & 267 & 41.0 & \\
\hline 2. & $\begin{array}{l}\text { Tipping is a good way to } \\
\text { motivate servers to take care } \\
\text { of customers }\end{array}$ & 8 & 1.2 & 22 & 3.4 & 74 & 11.4 & 291 & 44.7 & 256 & 39.3 & 4.2 \\
\hline 3. & $\begin{array}{l}\text { I support the custom of } \\
\text { tipping }\end{array}$ & 55 & 8.4 & 47 & 7.2 & 181 & 27.8 & 214 & 32.9 & 154 & 23.7 & 3.6 \\
\hline
\end{tabular}

Testing Research Hypotheses. This section aims to test the hypotheses of the research concerning the relationship between service quality attributes and customers' tipping behaviors as presented in Table (3).In order to test these hypotheses, the Pearson correlation coefficient " $r$ " which is a measure of the strength of the linear relationship between two variables was calculated between different service quality attributes and tipping behavior as presented below. " $\boldsymbol{R}$ " values supported the existence of a significant and positive relationship between all the attributes of service quality and tipping behavior $(\boldsymbol{r}>0, \mathrm{P}$-values $<0.05)$. But it is important to make it clear that the significance and strength of this relationship differed between the different attributes. Pearson correlation coefficient value proves that there is a significant and strong positive relationship between service quality and tipping behavior (P-value < 0.01 , with a correlation rate of $71.4 \%$ ), therefore the main hypothesis $(\mathrm{H}$.$) is$ supported.

From the results of the Pearson correlation test presented in Table (3), it can be seen that all sub-attributes of service quality are positively related with tipping behavior $(r>0$, P-values < 0.05). Therefore, all the sub-hypotheses are accepted. The most related sub-attribute with tipping behavior are both the speed of service and server attractiveness $(\mathrm{P}$-value $=0.000$, with a correlation rate of $51.5 \%)$, followed by server knowledge of menu items $(\mathrm{P}$-value $=0.000$, with a correlation rate of $50.7 \%)$, server friendliness $(\mathrm{P}$-value $=0.000$, with a correlation rate of $49.5 \%)$, server attentiveness $(\mathrm{P}-$ value $=0.000$, with a correlation rate of $41.2 \%$ ), the standing kind smile of service providers (P-value $=0.000$, with a correlation rate of $37.5 \%$ ) and finally good suggestions of menu items $(\mathrm{P}$-value $=0.000$, with a correlation rate of $36.8 \%)$.

Table 3: Correlation among Different Research Variables

\begin{tabular}{|c|c|c|c|c|c|c|c|c|c|}
\hline & & 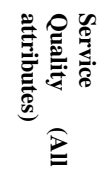 & 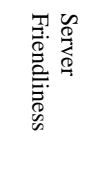 & 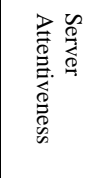 & 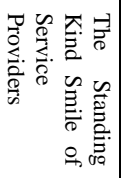 & 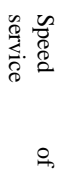 & 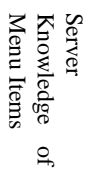 & 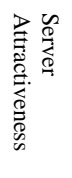 & 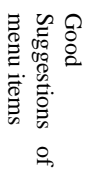 \\
\hline \multirow{2}{*}{$\begin{array}{l}\text { Service Quality } \\
\text { (All attributes) }\end{array}$} & Pearson Correlation & & & & & & & & \\
\hline & Sig. (2-tailed) & & & & & & & & \\
\hline \multirow{2}{*}{ Server Friendliness } & Pearson Correlation & $473^{* *}$ & & & & & & & \\
\hline & Sig. (2-tailed) & .000 & & & & & & & \\
\hline \multirow{2}{*}{$\begin{array}{l}\text { Server } \\
\text { Attentiveness }\end{array}$} & Pearson Correlation & $498^{* *}$ & $384^{* *}$ & & & & & & \\
\hline & Sig. (2-tailed) & .000 & .000 & & & & & & \\
\hline \multirow{2}{*}{$\begin{array}{l}\text { The Standing Kind } \\
\text { Smile of Service } \\
\text { Providers }\end{array}$} & Pearson Correlation & $418^{* *}$ & $345^{* *}$ & $.502^{* *}$ & & & & & \\
\hline & Sig. (2-tailed) & .000 & .000 & .000 & & & & & \\
\hline \multirow{2}{*}{ Speed of service } & Pearson Correlation & $.732^{* *}$ & $383^{* *}$ & $338^{* *}$ & $.185^{* *}$ & & & & \\
\hline & Sig. (2-tailed) & .000 & .000 & .000 & .000 & & & & \\
\hline
\end{tabular}




\begin{tabular}{|c|c|c|c|c|c|c|c|c|c|}
\hline \multirow{2}{*}{$\begin{array}{l}\text { Server Knowledge } \\
\text { of Menu Items }\end{array}$} & \multirow{2}{*}{$\begin{array}{l}\text { Pearson Correlation } \\
\text { Sig. (2-tailed) }\end{array}$} & $.752^{* *}$ & $361^{* *}$ & $.465^{* *}$ & $.422^{* *}$ & $.388^{* *}$ & & & \\
\hline & & .000 & .000 & .000 & .000 & .000 & & & \\
\hline \multirow{2}{*}{$\begin{array}{l}\text { Server } \\
\text { Attractiveness }\end{array}$} & \multirow{2}{*}{$\begin{array}{l}\text { Pearson Correlation } \\
\text { Sig. (2-tailed) }\end{array}$} & $803^{* *}$ & $.389^{* *}$ & $.454^{* *}$ & $.433^{* *}$ & $.457^{* *}$ & $.617^{* *}$ & & \\
\hline & & .000 & .000 & .000 & .000 & .000 & .000 & & \\
\hline \multirow{2}{*}{$\begin{array}{l}\text { Good Suggestions } \\
\text { of menu items }\end{array}$} & \multirow{2}{*}{$\begin{array}{l}\text { Pearson Correlation } \\
\text { Sig. (2-tailed) }\end{array}$} & $498^{* *}$ & $291^{* *}$ & $.363^{* *}$ & $439^{* *}$ & $263^{* *}$ & $.498^{* *}$ & $440^{* *}$ & \\
\hline & & .000 & .000 & .000 & .000 & .000 & .000 & .000 & \\
\hline \multirow{2}{*}{ Tipping Behavior } & \multirow{2}{*}{$\begin{array}{l}\text { Pearson Correlation } \\
\text { Sig. (2-tailed) }\end{array}$} & $.714^{* *}$ & $.495^{* *}$ & $.412^{* *}$ & $375^{* *}$ & $.515^{* *}$ & $.507^{* *}$ & $.515^{* *}$ & $.368^{* *}$ \\
\hline & & .000 & .000 & .000 & .000 & .000 & .000 & .000 & .000 \\
\hline
\end{tabular}

**Correlation is significant at the 0.01 level (2-tailed).

Discussion, Limitations and Directions for Future Research. This part represents a concise and comprehensive discussion of the findings in accordance with the objectives of the study. Collectively, results of the current study revealed that rewarding service quality is considered a very important determinant of customers' tipping behavior in Egyptian restaurants. Under the service quality dimension; speed of service and server attractiveness recorded the highest agreement as the most important reasons that stimulate customers' desire to leave tipping, followed by server knowledge of menu items, server friendliness, server attentiveness and the standing kind smile of service providers. The least important reason that might stimulate customers' desire to leave tipping under this dimension is good suggestions by waiters about menu items. This result conforms to previous researches and studies which confirmed that the desire to reward good service quality is the most common motive for tipping reported by customers in different parts of the world (e.g., Lynn, 2009; Lynn and Withiam, 2008; Koku, 2005; Azar, 2004; Lynn and McCall, 2000; Lynn and Graves, 1996). Moreover, the literature discussed the positive impact of various service quality attributes on customers' desirability to leave tipping. For example, when Jewell (2008) analyzed the impact of different service quality attributes on customers' desirability to leave tipping, server friendliness was the most important factor which motivated them to tip. Similarly, server attentiveness (Parrett, 2006; Lynn, 2000) and open-mouthed kind smiles (Tidd and Lockard, 1978) was positively correlated with customers' intention to leave tipping. The explanation for this finding is that Egyptians are very sociable people. Therefore they are highly affected by personality attractiveness, as well as they do appreciate friendly and attentive treatment of staff.

This research has a number of limitations that could suggest directions for future research. Firstly, although the great effort that had been made to gather responses for the questionnaire from a large number of customers, caution should be considered in generalizing the results, because of the huge population distributed among different remote Egyptian areas. For such a reason, convenience sample technique is used, as the researcher was unable to collect questionnaires in a random way. Therefore, future research should extend this effort by sampling a larger group of customers in different areas of Egypt, and in various types of restaurants as well. Secondly, although there are a large number of published researches about tipping motivations in western countries, there is a lack of researches that addressed the same issue in eastern and Arab countries. Since this is the uniqueness of such particular study, it is difficult to compare its findings with other eastern and Arab countries. So, future researches are needed to extensively explore the tipping customs and norms in eastern and Arab world, in order to show the similarities and differences between these nations. Additionally, other factors that affect the tipping behavior of restaurant customers, 
rather than service quality, have to be investigated in eastern and Arab countries. Finally, since the present research has drawn responses from customers, further research attempts should aim at investigating the same research hypothesis but from two points of view (customers and employees). This is very important to authenticate the results of this research, and to verify that customers' and staff members' visions are the same, or different. 


\section{Implications}

The findings of the current study have delineated valuable implications for restaurant managers. To begin with, restaurant managers should educate their employees that the most important motivator that encourages customers to leave tipping is to reward good service quality practices, such as friendliness and attentiveness. Keeping that result in mind, employees will be enthusiastic to ascertain more efforts to satisfy customers' needs, if they want to acquire increased tips. The following represent some important tips for customers on how to enhance service quality in order to increase tipping. Firstly, restaurant management should ensure that each moment of contact between the restaurant and the customer results in a positive experience for the guest. Managers must continuously remind contact employees how important their jobs are, by explaining to them how their jobs affect other people and the service they are offering. Secondly, superior managers have to look for opportunities to compliment employees for their jobs well done. Managers also need to set high standards for people and hold them accountable, because unless the managers require excellence from people and support them in their efforts, they cannot feel like winners.

Thirdly, to deliver service performance that inspires customer satisfaction, organizations must first understand what customers really want from a service transaction. Once identified and getting recognized; the next step is to ensure employees both understand and commit to service improvement goals. Fourthly, managers have to define and communicate the causes of service related problems with their employees. A constant flow of information facilitates the process of revealing root causes. Fifthly, train and educate service employees on the importance of the interaction process with the customer, and try to best manage hot spots and touch points that might help improving service quality and increase tipping. Awareness of the importance of a satisfied guest must be raised between staff and management. Employees can't be expected to appreciate customer satisfaction importance on their own; it is management's job to make them aware of its impact on everyone's success, and how their own behavior can increase or decrease customer satisfaction. Finally, service providers must be customer-focused; they should be able to listen, understand, communicate with, and relate to customers as well as demonstrate knowledge.

\section{Bibliography}

- Adams, J. S. (1965) 'Inequality in Social Exchange'. In: Berkowitz,L. (ed.) Advances in Experimental Social Psychology. New York: Academic Press Inc. pp. 267-299.

- Albrecht, K. and Zemke, R. (1985) Service America! Homewood. Cited in Severt,D. (2002) The Customer's Path to Loyalty: A Partial Test of the Relationships of Prior Experience, Justice, and Customer Satisfaction. $\mathrm{PhD}$. Thesis, Virginia State University.

- Azar, O. (2004) 'What sustains social norms and how they evolve? The case of tipping', Journal of Economic Behavior and Organization, 54(1), 49-64.

- Azar, O. (2007) 'Why pay extra? Tipping and the importance of social norms and feelings in economic theory', The Journal of Socio-Economics, 36(2), 250-265.

- Azar, O. (2009) 'Incentives and service quality in the restaurant industry: the tipping-service puzzle', Applied Economics, 41(15), 1917-1927.

- Azar, O. (2010) 'Tipping motivations and behavior in the U.S. and Israel', Journal of Applied Social Psychology, 40(2), 421-457.

- Azar, O. (2011) 'Business strategy and the social norm of tipping', Journal of Economic Psychology, 32(3), 515-525.

- Becker, C., Bradley, T. and Zantow, K. (2012) 'The underling dimensions of tipping behavior: An exploration, confirmation and predictive model', International Journal of Hospitality Management,31(1), 247-256. 
- Ben-Zion, U. and Karni, E. (1977)‘Tip Payments and the Quality of Service’. In: Orley, C. and Wallace, E. (eds.)Essays in Labor Market Analysis. New York: John Wiley and Sons.pp. 37-44.

- Berry, L., Zeithaml, V. and Parasuraman, A. (1985) 'Quality counts in services too', Business Horizon, 28(3), pp. 44-52.

- Bodvarsson, B. and Gibson, A. (1997) 'Economics and restaurant gratuities: Determining tip rates', American Journal of Economics and Sociology,56(2), 187-204.

- Brauer, J. (1997)'Tipping your waiter: A useful formula for employee compensation'. Cited in Lynn, M. and Withiam, G. (2008) 'Tipping and its alternatives: business considerations and directions for research', Journal of Services Marketing,22(4), 328-336.

- Callan, R. and Tyson, K. (2000) 'Tipping behaviour in hospitality embodying a comparative prolegomenon of English and Italian customers', Tourism and Hospitality Research, 2(3), 242261

- Casey, B. (2001) 'Tipping in New Zealand restaurants', International Journal of Hospitality Management, 20(2), 219-225.

- Conlin, M., Lynn, M. and O’Donoghue, T. (2003) 'The norm of restaurant tipping', Journal of Economic Behavior and Organization, 52(3), 297-321.

- Dewald, B. (2003) 'Tipping in HongKong restaurants', International Journal of Hospitality Management, 22(3), 307-319.

- Douglas, L. and Connor, R. (2003) 'Attitudes to service quality - the expectation gap', Nutrition \& Food Science,33(4), 165-172.

- Fornell, C. (1992) 'A national customer satisfaction barometer: The Swedish experience', Journal of Marketing, 56(1), 6-21.

- Gale, B. (1992) 'Monitoring customer satisfaction and market-perceived quality', American Marketing Association. Worth Repeating Series, No. 922CSO I. Chicago: American Marketing Association.

- Garvin, D. (1987) 'Competing on the eight dimensions of quality', Harvard Business Review, 65(6), 101109.

- Gronroos, C. (1990) 'Service Management: A Management Focus for Service Competition', International Journal of Service Industry Management, 1(1), pp.6-14.

- Hamilton, S. (2010) 'Ten of the best ... rules on tipping around the world'[online].The Guardian, 29 October.Available from:http://www.theguardian.com/money/2010/oct/29/ten-fo-the-besttipping-world [Accessed 5 January 2015].

- Heskett, J., Sasser, W. and Hart, C. (1990) Service Breakthroughs: Changing the Rules of the Game. New York: The Free Press.

- Ineson, E. and Martin, A. (1999) 'Factors influencing the tipping propensity of restaurant customers', Journal of Retailing and Consumer Service, 6(1), 27-37.

- Jewell, N. (2008) 'Factors influencing tipping behavior in a restaurant', Psi Chi Journal of Undergraduate Research, 13(1), 38-48.

- Kandampully, J. (1998) 'Service quality to service loyalty: A relationship which goes beyond customer services', Journal of Total Quality Management, 9(6), 431-443.

- Kandampully, J., Moke, C. and Sparks, B. (2002) Service Quality Management in Hospitality, Tourism, and Leisure. New York: Haworth hospitality press.

- King, C. (1995) 'What is hospitality?'International Journal of Hospitality Management, 14(3/4), 219-243.

- King, Z. and Woods, H. (1996)Quality Leadership Management in the Hospitality Industry. New York: Educational Institute of the American Hotel and Motel Association.

- Koku, S. (2005) 'Is there a difference in tipping in restaurant versus non-restaurant service encounters, and do ethnicity and gender matter?'Journal of Services Marketing,19(7), 445-452.

- Kwortnik, R., Lynn, M. and Ross, W. (2009) 'Buyer monitoring: A means to insure personalized service', Journal of Marketing Research, 46(5), 573-583.

- Lewis, R. and Booms, B. (1983) 'The Marketing Aspects of Service Quality'. In: Berry, L. L., Shostack, G. L.and Upah, G. D. (eds.) Emerging Perspectives on Services Marketing. Chicago: American Marketing Association, 99-107.

- Lin, E. (2013) 'False Gratuity: Where does that 10 percent service charge in restaurants go? Ahint: Not to your server' [online].Taipei Times Journal, 9 July. Available from:http://www.taipeitimes.com/News/feat/archives/2013/07/09/2003566663/2 [Accessed 5 January 2015]. 
- Loose, C. (2006) 'A few tips on handling gratuities worldwide' [online]. Washington Post Journal, 27 April. Available from:http://www.sfgate.com/entertainment/article/A-few-tips-onhandling-gratuities-worldwide-2519762.php [Accessed 5 January 2015].

- Lynn, M. (1997) 'Tipping customs and status seeking: A cross-country study', International Journal of Hospitality Management, 16(2), 221-224.

- Lynn, M. (2000) 'National character and tipping customs: the needs for achievement, affiliation and power as predictors of the prevalence of tipping', International Journal of Hospitality Management, 19(2), 205210.

- Lynn, M. (2001) 'Restaurant tipping and service quality: A Tenuous relationship', Cornell Hotel and Restaurant Administration Quarterly, 42(1), 14-20.

- Lynn, M. (2008) 'Personality effects on tipping attitudes, self-reported behaviors and customs: A multi-level inquiry', Personality and Individual Differences, 44(4), 989-999.

- Lynn, M. (2009) 'Individual differences in self-attributed motives for tipping: Antecedents, consequences and implications', International Journal of Hospitality Management, 28(3), 432-438.

- Lynn, M. (2011) 'Mega Tips 2: Twenty tested techniques to increase your tips' [online], Cornell Hospitality Tools, 2(1), 6-21. $\quad$ Available http://scholarship.sha.cornell.edu/cgi/viewcontent.cgi?article=1009\&context=chrtools [Accessed 11 January 2015].

- Lynn, M. and Grassman, A. (1990) 'Restaurant tipping: An examination of three rational explanations', Journal of Economic Psychology, 11(2), 169-181.

- Lynn, M. and Graves, J. (1996) 'Tipping: An incentive/reward for service?'Hospitality Research Journal,20(1), 1-14.

- Lynn, M. and Latané, B. (1984) 'The psychology of restaurant tipping', Journal of Applied Social Psychology, 14(6), 549-561.

- Lynn, M. and McCall, M. (2000) 'Gratitude and gratuity: A meta-analysis of research on the servicetipping relationship', Journal of Socio-Economics, 29(2), 203-214.

- Lynn, M. and Withiam, G. (2008) 'Tipping and its alternatives: business considerations and directions for research', Journal of Services Marketing, 22(4), 328-336.

- Maynard, L. and Mupandawana, M. (2009) 'Tipping behavior in Canadian restaurants', International Journal of Hospitality Management, 28(4), 597-603.

- Medler-Liraz, H. (2012) 'Service quality and tipping: The moderating role of the quality of food', International Journal of Hospitality Management, 31(4), 1327-1329.

- Murphy, T. and CNT Editors (2015) 'Etiquette 101: Your Guide to Tipping in 50 Countries' [online]. CNT: Condé Nast Traveler, 26 March. Available from: http://www.cntraveler.com/ stories/2008-11-11/etiquette-101-tipping-guide [Accessed 7 April 2015].

- National Restaurant Association, Research Dept. (1994) Foodservice 2050: A Glimpse at the Future of Foodservice Industry. Washington, DC.: National Restaurant Association. Cited in: Neal, D. (2004) 'The effect of length of stay on travelers' perceived satisfaction with service quality', Journal of Quality Assurance in Hospitality and Tourism, 4(3/4), $167-176$.

- National Restaurant Association, Research Dept. (1996) Table service Operator Survey. Washington, DC.: National Restaurant Association. Cited in: Neal, D. (2004) 'The effect of length of stay on travelers' perceived satisfaction with service quality', Journal of Quality Assurance in Hospitality and Tourism, 4(3/4), $167-176$.

- Nunnally, J. C. (1978) Psychometric Theory .New York: McGraw-Hill.

- Parasuraman, A., Zeithaml, V. and Berry, L. (1985) 'A conceptual model of service quality and its implications for future research', Journal of Marketing, 49(4), 41-50.

- Parasuraman, A., Zeithaml, V. and Berry, L. (1994) 'Reassessment of expectations as a comparison standard in measuring service quality: Implications for further research', Journal of Marketing, 58(1), 111124.

- Parret, M. (2006) 'An analysis of the determinants of tipping behavior: A laboratory experiment and evidence from restaurant tipping', Southern Economic Journal, 73(2), 489-514.

- Rodgers, G. (2010) Tipping in Asia: When, Where, and How Much Should You Tip? [online].Available from:http://goasia.about.com/od/Customs-and-Traditions/a/Tipping-inAsia.htm [Accessed 5 January 2015].

- Rotondo, M. (2014) How to tip when traveling around the world[online]. 16 September. Available from:http://www.fodors.com/news/how-to-tip-when-traveling-around-the-world-10820.html [Accessed 5 January 2015]. 
- Saunders, G. and Lynn, M. (2010) 'Why Tip? An empirical test of motivations for tipping car guards', Journal of Economic Psychology,31(1), 106-113.

- Schmitt, N. (1996) 'Uses and abuses of coefficient Alpha', Psychological Assessment, 8(4), 350353.

- Snyder, L. (1976) 'The inverse relationship between restaurant party size and tip percentage: Diffusion or equity?' Personality and Social Psychology Bulletin, 2(3), 308.

- Speer, T. (1997) 'The give and take of tipping', American Demographics, (February), 51-54.

- Strand, O. (2014) 'How Japan Has Perfected Hospitality Culture' [online]. The Wall Street Journal. 1 May. Available from: http://www.wsj.com/news/articles/SB1000142405270230345 6104579489824193262260 [Accessed 23Decembery 2014].

- Tidd, L. and Lockard, S. (1978) 'Monetary significance of the Affiliative smile: A case for reciprocal altruism', Bulletin of the Psychonomic Society, 11(6), 344-346.

- Van Vaarenbergh, Y. and Holmqvist, J. (2013) 'Speak my language if you want my money: Service language's influence on consumer tipping behavior', European Journal of Marketing, 47(8), 1276-1292.

- Videbeck, S. (2004) 'The economics and etiquette of tipping', Policy: A Journal of Public Policy and Ideas, 20(4), 38-41.

- Walster, E., Berscheid, E. and Walster, W. (1973) 'New directions in equity research', Journal of Personality and Social Psychology, 25(2), 151-176.

- Wessel, J. (1997) 'Minimum wages and tipped server', Economic Inquiry Journal,35(2), 334-349.

- Whaley, J. (2011)What's in a Tip? An Exploratory Study of the Motivations Driving Consumer Tipping Behavior. PhD. Thesis, Auburn University. Auburn, Alabama.

- Whaley, J., Douglas, A. and O'Neill, M.(2014) 'What's in a tip? The creation and refinement of a Restaurant-Tipping Motivations Scale: A consumer perspective', International Journal of Hospitality Management, 37(February 2014), 121-130.

- Wyckoff, D. (2001) 'New Tools for Achieving Service Quality', Cornell Hotel and Restaurant Administration Quarterly, 42(4), 25-38.

- Yesiltas, M., Zorlu, O., Sop, S. and Beydilli, E. (2014) 'The effects of service quality on customers' tipping behavior', International Journal of Academic Research in Business and Social Sciences, 4(8) 430-446.

- Zahari, M., Rashdi, O., Radzi, M. and Othman, Z. (2011) 'Tipping: has it becoming prevalent norms in Malaysia hospitality industry?'Journal of Tourism, Hospitality and Culinary Arts, 3(3), 39-52.

- Zeithaml, V., Berry, L. and Parasuraman, A. (1988) 'Communication and control processes in the delivery of service quality’, Journal of Marketing, 52(2), 35-48.

- Zeithaml, V., Berry, L. and Parasuraman, A. (1996) 'The behavioral consequences of service quality', Journal of Marketing, 60(2), 31-46.

- Zeithmal, V. and Bitner, M. (2003) Service Marketing: Integrating Customer Focus Across the Firm. New York: McGraw-Hill.

- Zemke, R. and Schaap, D. (1989)The Service Edge: 101 Companies that Profit from Customer Care. New York: NAL penguin. 